\title{
The Forms of the Affects
}




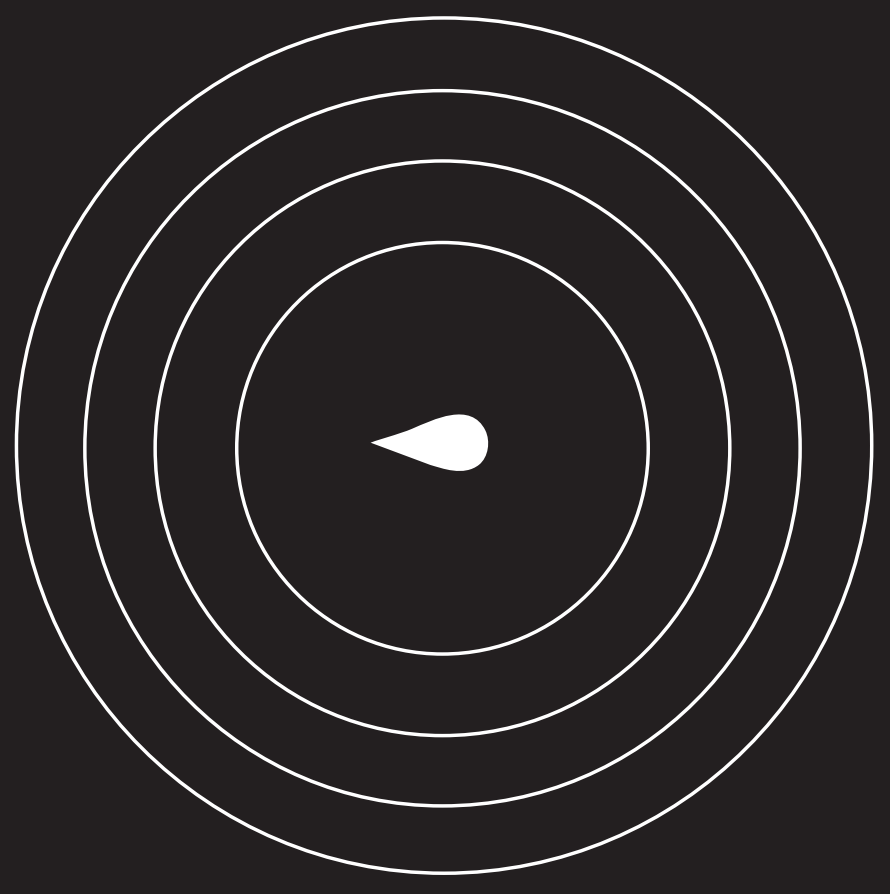




\section{The Forms}

\section{of the Affects}

\section{$\checkmark$}

Eugenie Brinkema 
(C) 2014 DUKE UNIVERSITY PRESS

ALL RIGHTS RESERVED

PRINTED IN THE UNITED STATES OF AMERICA

ON ACID-FREE PAPER $\infty$

DESIGNED BY AMY RUTH BUCHANAN

TYPESET IN MINION PRO BY COPPERLINE BOOK

SERVICES, INC.

LIBRARY OF CONGRESS CATALOGING-IN-PUBLICATION DATA BRINKEMA, EUGENIE, 1980-

THE FORMS OF THE AFFECTS / EUGENIE BRINKEMA.

P. CM.

INCLUDES BIBLIOGRAPHICAL REFERENCES AND INDEX.

ISBN 978-0-8223-5644-8 (CLOTH : ALK. PAPER)

ISBN 978-0-8223-5656-1 (PBK. : ALK. PAPER)

1. FILM CRITICISM. 2. FORMALISM (LITERARY ANALYSIS).

3. AFFECT (PSYCHOLOGY). 4. CRITICAL THEORY. I. TITLE.

PN1995.B75 2014

$791.4301^{\prime} 5-D C 23$

2013037965

DUKE UNIVERSITY PRESS GRATEFULLY ACKNOWLEDGES THE SUPPORT OF THE MASSACHUSETTS INSTITUTE OF TECHNOLOGY, LITERATURE SECTION, WHICH PROVIDED FUNDS TOWARD THE PUBLICATION OF THIS BOOK. 
TO MY MOTHER, TO MY FATHER 

I shall consider human actions and desires

in exactly the same manner,

as though I were concerned with lines, planes, and solids.

-BARUCH SPINOZA

It is the force, at once simple and unexpected,

which consists in saying cinema and ... :

and thus accepting all the consequences.

-RAYMOND BELLOUR 
